\title{
Soft Tissue Sarcoma of the Abdomen and Thoracic Visceral Organs Pathologic TNM Finding v8
}

National Cancer Institute

\section{Source}

National Cancer Institute. Soft Tissue Sarcoma of the Abdomen and Thoracic Visceral

Organs Pathologic TNM Finding v8. NCI Thesaurus. Code C136729.

A pathologic finding about one or more characteristics of soft tissue sarcoma of the abdomen and thoracic visceral organs, following the rules of the TNM AJCC V8 classification system. 